\title{
Viljelykierto ja monipuolinen kasvilajisto peltomaan hyötymikrobiston edistäjänä
}

Ansa Palojärvi ${ }_{1}$, Mauritz Vestberg ${ }_{2}$, Timo Sipilä ${ }_{1) 3}$,, Pauliina Lankinen ${ }_{4)}$, Kim Yrjälä ${ }_{5}$, Marjo Keskitalo ${ }_{1)}$ ja Laura Alakukku 3 )

${ }^{1)}$ MTT Kasvintuotannon tutkimus, 31600 Jokioinen, ansa.palojarvi@mtt.fi. marjo.keskitalo@mtt.fi

${ }^{2)}$ MTT Kasvintuotannon tutkimus, 41330 Vihtavuori, mauritz.vestberg@mtt.fi

${ }^{3)}$ Maataloustieteiden laitos, 00014 Helsingin yliopisto, timo.p.sipila@helsinki.fi. laura.alakukku@helsinki.fi

${ }^{4)}$ Elintarvike- ja ympäristötieteiden laitos, 00014 Helsingin yliopisto, pauliina.lankinen@helsinki.fi

${ }^{5)}$ Biotieteiden laitos, 00014 Helsingin yliopisto, kim.yrjala@helsinki.fi

\section{Tiivistelmä}

Tavoiteltaessa "vihreämpää maataloutta" peltomaan mikrobiston toiminnan merkitys korostuu entisestään. Maaperämikrobisto vastaa kasvintähteiden hajotuksesta ja eloperäisessä muodossa olevien ravinteiden vapauttamisesta satokasvien käyttöön. Mykorritsasienet voivat kasvin kanssa muodostuvan ns. sienijuuren avulla tehostaa kasvien fosforin saantia ja suojata kasvia stressitekijöiltä (mm. kuivuus, kasvitaudit). Monimuotoisen mikrobiston on todettu parantavan maaperän luontaista tautisuppressiivisuutta (kasvitautimikrobien kasvun tukahduttaminen).

Mikrobisto on runsainta kasvin juuristossa ja sen välittömässä läheisyydessä ("ritsosfääriefekti"). Kasvi luovuttaa yhteyttämistuotteitaan juurieritteiden muodossa ja muokkaa maaperän olosuhteita mikrobeille suotuisiksi. Monivuotisilla kasveilla juuriston koko suhteessa maan yläpuoliseen biomassaan on suurempi kuin yksivuotisilla kasveilla. Monivuotisilla kasveilla juuristo kasvaa koko kasvukauden, kun se yksivuotisilla on laajimmillaan tuleentumisen aikoihin. Kasvilajeilla on kuitenkin suuria eroja juuriston koossa ja juurieritteissä, ja vain osa lajeista kykenee muodostamaan sienijuuren mykorritsasienten kanssa.

Tutkimustemme tavoitteena oli selvittää, voidaanko peltomaan mikrobistoon vaikuttaa viljelykierron ja kasvilajivalikoiman avulla. Esitykseen kootaan tuloksia kahdesta tutkimuksesta, jotka molemmat on toteutettu MTT Jokioisilla.

MONIKASVI-hankkeen 3-vuotisessa kenttäkokeessa keskityimme juuriston ja sen ympäröivän maan mikrobistoon. Kokeessa oli mukana viisi yksivuotista (ohra (Hordeum vulgare), kinua (Chenopodium quinoa), camelina (Camelina sativa), pellava (Linum usitatissimum) ja tattari (Fagopyrum esculentum)) ja viisi monivuotista (timotei (Phleum pratense), kumina (Carum carvi), ruokohelpi (Phalaris arundinacea), värimorsinko (Isatis tinctoria), nokkonen (Urtica dioica)) viljelykasvia. SUCCESS-hankkeessa vertailimme maaperän mikrobistoa 4-vuotisessa viljelykierrossa (kevätvehnä, rypsi, ohra, herne) ja jatkuvassa kevätvehnän viljelyssä. Vertailussa olivat myös muokkausmenetelmät kyntö ja suorakylvö. Maaperämikrobiston koostumusta selvitettiin fosfolipidirasvahappojen (PLFA) ja neutraalilipidirasvahappojen (NLFA) analyysien avulla. MONIKASVI-hankkeessa selvitettiin arbuskelimykorritsojen esiintymistä myös muilla menetelmillä. SUCCESS-hankkeessa analysoitiin mikrobiston koostumusta molekyylibiologisilla menetelmillä, sekä selvitettiin mikrosienten esiintymistä oljessa.

Peltomaan mikrobiston esiintymisessä oli suuria eroja kasvilajien välillä. Monivuotiset kasvit ylläpitivät runsaampaa mikrobistoa. Arbuskelimykorritsan esiintymiseen vaikutti ensisijaisesti kasvilajin ominaisuudet. Viljelykierrolla ja muokkausmenetelmällä voidaan edistää toivotunlaisen mikrobiston esiintymistä maassa.

Asiasanat: viljelykierto, viljelykasvi, maaperä, mikrobisto, mykorritsa, tautisuppressiivisuus 


\section{Johdanto}

Tavoiteltaessa "vihreämpää maataloutta" peltomaan mikrobiston toiminnan merkitys korostuu entisestään. Maaperämikrobisto vastaa kasvintähteiden hajotuksesta ja eloperäisessä muodossa olevien ravinteiden vapauttamisesta satokasvien käyttöön. Kasvin kasvun kannalta hyödyllisiä ovat typen- ja fosforinsaannissa avustavat symbionttiset mikrobit ja muut kasvin ravinteiden ottoa tehostavat mikrobit, kasvin kasvua edistäviä yhdisteitä tuottavat mikrobit sekä kasvitauteja estävät tai tukahduttavat mikrobit. Mikrobit osallistuvat kasvitautien torjuntaan (biokontrolli) tuottamalla mm. antibiootteja (Bowen \& Rovira 1991). Antibiootteja tuottavat muun muassa monet aktinobakteerit. De Boer ym. (2007) osoittivat, että kasvitautien tukahduttaminen (tautisuppressiivisuus) ei ole välttämättä yksittäisten mikrobilajien aiheuttamaa, vaan usean mikrobilajin yhteistyötä. Myös monimuotoisen mikrobiston on yleisemminkin todettu parantavan maaperän luontaista tautisuppressiivisuutta.

Mikrobisto on runsainta kasvin juuristossa ja sen välittömässä läheisyydessä ("ritsosfääriefekti"). Juurieritteet määräävät suurelta osin ritsosfäärin mikrobien määrän ja laadun, ja mikrobiyhteisö onkin erilainen ritsosfäärissä kuin sen ulkopuolella (Bowen \& Rovira 1991). Kasvi luovuttaa yhteyttämistuotteitaan juurieritteiden muodossa ja muokkaa maaperän olosuhteita mikrobeille suotuisiksi. Mykorritsasienet voivat kasvin kanssa muodostuvan ns. sienijuuren avulla tehostaa kasvien fosforin saantia ja suojata kasvia stressitekijöiltä (mm. kuivuus, kasvitaudit).

Monivuotisilla kasveilla juuriston koko suhteessa maan yläpuoliseen biomassaan on suurempi kuin yksivuotisilla kasveilla. Monivuotisilla kasveilla juuristo kasvaa koko kasvukauden, kun se yksivuotisilla on laajimmillaan kukinnan aikoihin. Kasvilajeilla on kuitenkin suuria eroja juuriston koossa ja juurieritteissä. Vain osa kasvilajeista kykenee muodostamaan sienijuuren mykorritsasienten kanssa. Arbuskelimykorritsan sienirihmat voivat parantaa maan rakennetta sitomalla pienempiä partikkeleita yhteen ja erittämällä murujen muodostusta edistävää glykoproteiinia, glomaliinia (Rillig 2004). Kasvilajivalikoimalla ja viljelykierrolla on keskeinen merkitys eloperäisen aineksen määrään (olki ym. kasvinjätteet, juuristo), ja laatuun (kasvi- ja juurimateriaalin laatu, juurieritteiden laatu) peltomaassa.

Tutkimustemme tavoitteena oli selvittää, voidaanko peltomaan mikrobistoon vaikuttaa viljelykierron ja kasvilajivalikoiman avulla. Esitykseen kootaan tuloksia kahdesta tutkimuksesta, jotka molemmat on toteutettu MTT Jokioisilla.

\section{Aineisto ja menetelmät \\ Kenttäkokeet}

Kenttäkokeet perustettiin Jokioisille, Maa- ja elintarviketalouden tutkimuskeskuksen (MTT) koepelloille. MONIKASVI-kenttäkokeen maalaji oli hietasavi ja SUCCESS-kenttäkokeessa aitosavi. MONIKASVIhankkeen 3-vuotisessa kenttäkokeessa keskityimme juuriston ja sen ympäröivän maan mikrobistoon. SUCCESS-hankkeessa vertailimme maaperän mikrobistoa 4-vuotisessa viljelykierrossa (kevätvehnä, rypsi, ohra, herne) ja jatkuvassa kevätvehnän viljelyssä. Vertailussa olivat myös muokkausmenetelmät kyntö ja suorakylvö.

MONIKASVI-kokeessa oli mukana viisi yksivuotista kasvia (ohra (Hordeum vulgare), kinua (Chenopodium quinoa), camelina (Camelina sativa), pellava (Linum usitatissimum) ja tattari (Fagopyrum esculentum)) ja viisi kaksi- tai monivuotista (timotei (Phleum pratense), kumina (Carum carvi), ruokohelpi (Phalaris arundinacea), värimorsinko (Isatis tinctoria), nokkonen (Urtica dioica)) viljelykasvia. Koekasvilajeista viiden tiedetään olevan mykorritsallisia eli muodostavan sienijuuren arbuskelimykorritsasienten (AM-mykorritsasieni) kanssa. Näitä kasveja ovat ohra, pellava, ruokohelpi, timotei ja kumina. Kasvilajeista tattari, camelina (kitupellava) ja nokkonen taas ovat mykorritsattomia kasveja, eli eivät sienijuurta muodosta. Tiedot värimorsingon ja kinuan kyvystä muodostaa sienijuuri ovat vähäiset, mutta todennäköisesti ne ovat vähän tai ei lainkaan mykorritsallisia kasveja (ks. Palojärvi ym. 201x).

MONIKASVI-kokeen erikoiskasvit oli valittu tutkimukseen sen perusteella, että niillä voidaan olettaa olevan taloudellista hyötyä viljelijälle. Kinua ja tattari sopivat keliakiasta kärsivien ruokavalioon. Camelinasta ja pellavasta saadaan terveellistä öljyä ravinnoksi. Pellavaöljyllä on laajempaakin käyttöä $\mathrm{mm}$. maalien ainesosana ja pellavasta saadaan kuitua tekstiiliteollisuudelle. Kuminaa tuotetaan mausteeksi 
ja kuminaöljyn käyttömahdollisuuksia on selvitetty biotorjunta-aineena. Ruokohelpi sopii bioenergian tuotantoon, kun taas värimorsingosta saadaan indigo-väriainetta ja nokkosta viljellään kuitukasvina (ks. Keskitalo ym. 2007).

\section{Analyysit}

Maaperämikrobiston koostumusta ja kasvin kasvun kannalta hyödyllisten mikrobien esiintymistä selvitettiin fosfolipidirasvahappojen (PLFA; phospholipid fatty acids) ja neutraalilipidi-rasvahappojen (NLFA; neutral lipid fatty acids) analyysien avulla (Palojärvi 2006). PLFA:n kokonaismäärää käytettiin

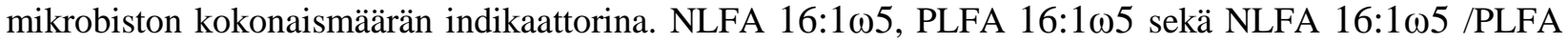

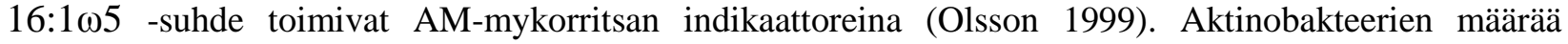
arvioitiin PLFA p10-17:0 ja p10-19:0 määrien summana.

MONIKASVI-hankkeessa mikrobiston koostumus analysoitiin erikseen ritsosfäärimaasta aivan juuriston läheisyydestä ja muualta ympäröivästä maasta (Schmalenberger \& Tebbe 2003). Lisäksi selvitettiin tutkimuskasvien juurten infektoitumista AM-mykorritsoilla mikroskopoimalla, sekä arvioitiin AM-sienten lisääntymisosien esiintymistä maassa MPN (most probable number) -menetelmillä (Vestberg ym. 2005, Vestberg ym. 2010). SUCCESS-hankkeessa analysoitiin mikrobiston koostumusta myös molekyylibiologisilla menetelmillä (Sipilä ym. 201x), sekä selvitettiin mikrosienten esiintymistä oljessa. Maaperän kemialliset analyysit tehtiin standardimenetelmillä.

\section{Tulokset ja tulosten tarkastelu}

MONIKASVI-hankkeen 3-vuotinen kenttäkoe osoitti, että kasvilajilla on vaikutusta peltomaan mikrobiston runsauteen. Erot kehittyivät melko hitaasti, mutta kolmen kasvukauden jälkeen monivuotiset kasvit ylläpitivät runsaampaa maaperän mikrobistoa yksivuotisiin kasveihin verrattuna. Samanlainen ero yksi- ja monivuotisten kasvien välillä oli havaittavissa, kun tarkasteltiin yksittäistä hyötymikrobien ryhmää aktinobakteereita.

Juuristomikrobiston yhteisörakenne erosi selvästi yksittäisten kasvilajien välillä. Esimerkiksi kuminan mikrobiyhteisö erosi selkeästi ohran mikrobiyhteisöstä kasvukauden lopussa, kun taas öljypellavalla ero ohraan oli vähäinen. Tulokset kuitenkin osoittivat, että ritsosfäärin ulkopuolella kasvilajien erot mikrobiyhteisöjen välillä pienenivät.

Arbuskelimykorritsan esiintymiseen vaikutti ensisijaisesti kasvilajin ominaisuudet. Kenttäkokeessa saatiin selvät erot mykorritsallisten ja mykorritsattomien kasvien maaperän AM-mykorritsan esiintymisessä. Mykorritsalliset kasvit lisäsivät AM-mykorritsan määrää sekä ritsosfäärimaassa että sen ulkopuolella. Kasvilajien välillä oli selkeitä eroja. Ruokohelpi osoittautui erittäin hyväksi AMmykorritsan suosijaksi (Vestberg ym. 2010).

Kun kasveja kasvatettiin kolme vuotta samalla lohkolla, kasvin kasvun kannalta hyödyllisten mikrobien määrä lisääntyi useimpien kasvien ritsosfäärissä. Tulosten perusteella erityisesti kumina, värimorsinko, kinua, nokkonen ja ruokohelpi vaikuttaisivat lupaavilta erikoiskasveilta maaperän mikrobiyhteisöjen monipuolistamiseksi. Valikoiduilla erikoiskasveilla voitaisiinkin mahdollisesti muuttaa peltomaan mikrobiyhteisön suuruutta ja rakennetta. Viljelykasvien valinnalla voitaisiin siten ohjata maaperän mikrobiyhteisöä viljelyn kannalta suotuisaan suuntaan.

SUCCESS-hankkeessa yhtenä tutkimuskenttänä oli kevätvehnän jatkuvan viljelyn ja 4-vuotisen viljelykierron (kevätvehnä, rypsi, ohra, herne) vertailu. Viljelykierrossa havaittiin tendenssi lisätä mikrobiston kokonaismäärää ja aktinobakteerien esiintymistä, sekä vähentää tautisienten esiintymistä maassa, mutta erot olivat vähäisemmät kuin muokkausmenetelmien (kyntö, suorakylvö) välillä (Sipilä ym. 201x). Kasvilajeista rypsi on mykorritsaton laji, mikä näkyi peltomaan AM-mykorritsan määrissä.

\section{Johtopäätökset}

Kasvilajivalinnalla voidaan vaikuttaa peltomaan mikrobistoon. Kasvin juurten lähellä olevassa ritsosfäärimaassa on runsaampi ja lajikoostumukseltaan toisenlainen mikrobisto kuin ympäröivässä maassa. Yksittäisillä kasvilajeilla on yksilöllisiä vaikutuksia mikrobistoon, sillä ne eroavat toisistaan juurieritteiden laadussa, määrässä ja mikrobisymbioosin muodostamisen kyvyssä. Monivuotiset kasvit 
ovat yleensä eduksi mikrobiston monimuotoisuudelle ja hyötymikrobien esiintymiselle yksivuotisiin viljelykasveihin verrattuna. Tärkeä syy monivuotisten kasvien suotuisaan vaikutukseen on laaja juuristo ja ja sen aktiivinen kasvu koko kasvukauden ajan. Viljeltävien kasvilajien valikoimaa lisäämällä ja monivuotisten kasvien suosimisella viljelykierroissa on mahdollista nostaa mikrobiston määrää ja monimuotoisuutta maassa, mikä samalla kasvattaa hyödyllisten mikrobien todennäköisyyttä esiintyä peltomaassa.

\section{Kirjallisuus}

Bowen, G.D. \& Rovira, A.D. 1991. The rhizosphere - the hidden half of the hidden half. Teoksessa: Waisel, Y., Eshel, A. \& Kafkafi, U. (toim). Plant roots - the hidden half. New York, USA: Marcel Dekker, Inc. s. 641-669.

De Boer, W., Verheggen, P., Klein Gunnewiek, P.J., Kowalchuk, G.A. \& Van Veen, J.A. 2003. Microbial Community Composition Affects Soil Fungistasis. Appl Environ Microbiol 69: 835-844.

De Boer, W., Wagenaar, A.M., Klein Gunnewiek, P.J. \& Van Veen, J.A. 2007. In vitro suppression of fungi caused by combinations of apparently non-antagonistic soil bacteria. FEMS Microbiol Ecol 59: 177-185.

Keskitalo, M. Hakala, K., Peltonen, S. \& Harmoinen, T. (toim.) 2007. Erikoiskasvien viljely. ProAgria Maaseutukeskusten Liiton julkaisuja 1034:Tieto tuottamaan 118: 95 s.

Olsson, P.A. 1999. Signature fatty acids provide tools for determination of the distribution and interactions of mycorrhizal fungi in soil. MiniReview. FEMS Microbiology Ecology 29: 303-310.

Palojärvi, A. 2006. Phospholipid fatty acid (PLFA) analyses. Teoksessa: Bloem, J., Hopkins, D.W, Benedetti A. (toim.) Microbiological methods for assessing soil quality. Wallingford, UK: CABI Publishing: ss. 204-211.

Rillig, M.C. 2004. Arbuscular mycorrhizae, glomalin, and soil aggregation. Canadian Journal of Soil Science 84: 355-363.

Schmalenberger, A. \& Tebbe, C.C. 2003. Bacterial diversity in maize rhizospheres: conclusions on the use of genetic profiles based on PCR-amplified partial small subunit rRNA genes in ecological studies. Molecular Ecology 12: 251261.

Sipilä, T.P., Yrjälä, K., Alakukku, L. \& Palojärvi, A. 201x (submitted). Cross site soil microbial communities under tillage regimes - connection between soil fungistasis and microbial biomarkers.

Vestberg, M., Saari, K., Kukkonen, S. \& Hurme, T. 2005. Mycotrophy of crops in rotation and soil amendment with peat influence the abundance and effectiveness of indigenous arbuscular mycorrhizal fungi in field soil. Mycorrhiza 15: 447-458.

Vestberg, M., Palojärvi, A., Puolakka, E., Pitkänen, T., Kaipainen, S. \& Keskitalo, M. 2010. Impact of host mycotrophy on AMF traits in a temperate agricultural soil as measured by the most probable number and signature fatty acid methods. Teoksessa: From production to application of arbuscular mycorrhizal fungi (AMF) in agricultural systems: a multidisciplinary approach. COST870 meeting in Jyväskylä, Finland, 13-15 December 2010, s. 43. 